\begin{tabular}{ccc}
\hline Mournals & MARKETING AND BRANDING & $\begin{array}{c}\text { INDUSTRIAL } \\
\text { RESEARCH } \\
\text { MANAGEMENT } \\
\text { AIMI }\end{array}$ \\
\hline \hline
\end{tabular}

\title{
Sport celebrities multiple use in marketing messages: Example of the Spanish tennis player Rafael Nadal
}

\author{
Arta Antonovica*, Javier de Esteban Curiel \\ Rey Juan Carlos University, Madrid, Spain
}

\begin{abstract}
Keywords:

Message Source, Sport Celebrity, Marketing

Endorsers, Serial

Advertiser, Semiotics,

Content Analysis, Rafael Nadal

Correspondence:

The use of a sport celebrity as a message source is a popular way how to convince many consumers around the world to buy and use different services. In the last decades, we have seen that many sport celebrities in a serial way promote products and services of different companies at the same time or in a sequence. Therefore, there arises a question of message source credibility and trustfulness. The main objective of this research paper is to study the world famous Spanish tennis player's appearance, Rafael Nadal, as a message source in different companies' advertisements and the kind of image he creates. In this sense, a content analysis technique and a face-to-face survey technique (328 subjects) have been conducted to know what the consumers' attitudes towards serial sport endorsers are.
\end{abstract}

arta.antonovica@urjc.es

(C)AIMI Journals

From the beginning of the ads use for promoting different products and services, there have been chosen nationally and internationally famous celebrities as a message source or in other words, product and service endorsers. Most of the times, these endorsers have presented diverse professions such as musicians, actors, dancers, fashion models, writers, experts in some particular area, and sportsmen. These celebrities are contracted to promote and convince consumers to buy products to which they are related or not related at all. They can create some imaginary or realistic characters which convert consumer's personality or life by using particular product or service. As we have mentioned before, also world famous sportsmen and sportswomen have appeared in different companies ads. In this sense, the authors of this research have analysed the Spanish tennis player Rafael Nadal's presence in the advertisement world. During the last decade Rafael Nadal has been on the top of tennis 
charts which helped him to be noticed in the advertisement sphere and be inspiration for all age's people to practice sports, and also for ordinary or particular consumers to buy products which are promoted by him. Rafael Nadal has been promoting from sports clothing to cookies, from luxury watches to insurance services, from males fragrances to males underwear and many other products related and not related to his professional sports career. His image in ads has been reflected image from seductive male to professional tennis player, and from funny young guy to serious sports man.

From marketing studies point of view, any personalities or objects used in ad does not present directly the product or service per se but some signs which are important for some certain persons or group of people. On the other hand, it is very important for each company that an image/sign which has been used in its advertising materials creates strong consumers' bonding to their products and services. Moreover, here arises many questions: what happens if a sports celebrity should create image of many different products and services at the same time or in a sequence? What image will be saved of specific product/service in consumers' mind if the used celebrity appears in many ads? Is it a loose of money for a company by using a serial advertiser? Is it creating a false image for a company by using a serial advertiser? What is credibility of these ads where a sports celebrity appears too many times and in too different products? Therefore, the main objective for the authors of this research project is to find out what image a tennis player Rafael Nadal creates as a serial advertiser in the Spanish consumers' mind.

\section{The Literature review}

\section{Marketing Message Source Credibility and Attractiveness}

The source of a marketing message can have a big impact on the likelihood that the message will be accepted among the potential or existing consumers. Those who are appealing and trustworthy can be chosen as a source. In this sense, the source may be an individual (a salesperson or a celebrity) or a nonperson entity (corporation or organization itself), but two particularly important source characteristics are credibility and attractiveness (Belch \& Belch, 2012; Solomon, Bamossy, Askegaard, \& Hogg, 2006). The target market consumers are easily persuaded when the message source possesses a highly credibility in their eyes. However, the source credibility includes the characteristics of trustworthiness and expertise. It is assumed that a source is generally viewed as trustworthy when the complete and accurate information is provided by him/her. However, product and service knowledge is required for a source to have expertise and no apparent motive to mislead others. In addition, source credibility can influence persuasion in various situations: For instance, a credible source can enhance attitudes when consumers lack the ability or motivation to form direct judgements of the product's performance and a credible source can enhance message processing and acceptance (Hawkins \& Mothersbaugh, 2013). Posited by Solomon et al. (2006), the source attractiveness is achieved by source's perceived social value, i.e., when a source resembles to the receiver in terms of physical appearance, personality, and social status make him invaluable and attractive even if he is dead. 


\section{Celebrities as a Message Source}

Celebrities are widely used as message sources. Nowadays, many companies all over the world commit their resources to celebrity endorsement of their brands as a form or marketing communications. Many TV stars, movie stars, athletes, and models are engaged in various brand endorsement agreements with many companies to the tune of millions of dollars or euros. The practice increases daily (Kotler \& Armstrong, 2012). Celebrity sources are effective for a variety of reasons which are touched upon briefly below.

Attention: Consumers are attracted to the ads which celebrities appear in.

Attitude toward the Ad. Celebrities who are popular and admired can enhance brand attitudes. Trustworthiness: Since celebrities possess trustworthy, they develop highly reliable public persons' image that consumers trust. This trust translates into purchases.

Expertise: Some celebrities are also experts. This occurs frequently in areas such as music and sports.

Aspirational Aspects: Consumers may put themselves in celebrities' place and impersonate their style; consequently, they may buy similar brands and follow similar styles.

Meaning Transfer: Consumers may relate notable characteristics of the celebrity with that of the products that are compatible with their own needs or desires (Hawkins \& Mothersbaugh, 2013).

In contrast, using a celebrity as a message source creates a special risk for company: overexposure. If one celebrity endorses many different products and services, consumers' reactions may become less positive. Hence, this kind of celebrities can be seen as 'serial advertisers (Hawkins \& Mothersbaugh, 2013; Solomon et al., 2006).

\section{Sport Celebrities}

The use of sport celebrities as a message source is important aspect in marketing to target market sport fans and other market segments. Sports celebrities enhance consumer recognition and image awareness of brands the athletes represent (Keller, 1998). Also his kind of celebrities are widely used in product advertising to drive sales by improving consumers' product recall and positively influencing their brand choice behaviour (Ruihley, Runyan, \& Lear, 2010). Therefore, a successful message source requires, at a minimum, that a celebrity athlete is both among the top performers in his/her sport and able to project a likeable and trustworthy persona to consumers (Stone, Joseph, \& Jones, 2003). In this sense, among the most successful endorsement arrangements are those in which the celebrity athlete's success can be directly related to the product/ service and particularly when the product is sports equipment or athletic footwear (Misra \& Beatty, 1990; Stone et al., 2003). On the other hand, some research suggests that where no such congruence exists, the audience will remember the celebrity and not the product which has been advertised (Evans, 1988).

\section{Semiotics in Marketing Studies}

Semiotics origins can be traced back as far as Plato and Augustine, but semiotics as selfconscious theory emerged only at the beginning of the 20th century, in the writing of Charles Sanders Peirce and Ferdinand de Saussure. Semiotics studies signification dealing with 
human subjects and culture (Silverman, 1983). In addition, an academic Eco affirms that semiotics studies all cultural processes as processes of communication.

Hence, we wouldi like to go back to the beginning of the modern understanding of semiotics, and in this sense, a Saussure's model of sign is in the dyadic tradition in which the two parts of a sign consist of a sign vehicle and its meaning. Therefore, Professor Saussure defined a sign as being composed of a "signifier" and a "signified". According to latest scholars, the former refers to the form that the sign acquires; the latter describes the concept to which it refers (Chandler, 2007). In contrast to the Saussure's model of dyadic tradition, Charles Sanders Peirce model consists of a triad, namely the sign, the interpretant, and the object. Signification is understood as involving all three in a complex interaction:

"A sign is something which stands to somebody for something in some respect or capacity. It addresses somebody, that is, creates in the mind of that person an equivalent sign, or perhaps a more developed sign. That sign which it creates I call the interpretent of the first sign. The sign stands for something, its object. It stands for that object, not in all respects, but in reference to a sort of idea, which I have sometimes called the ground" (Silverman, 1983, p. 14).

For that reason, Peirce's three concepts can be modelled as in Figure 1. The double-ended arrows emphasize that each term can be understood only in relation to the others. A "sign" refers to something other than itself- the "object", and is understood by somebody: that is, it has an effect in the mind of the user- the "interpretant". We must realize that the interpretant is not the user of the sign, but what Peirce calls "the proper significate effect": that is, it is a mental concept produced both by the sign and by the user's experience of the object (Fiske, 2010, p. 41).

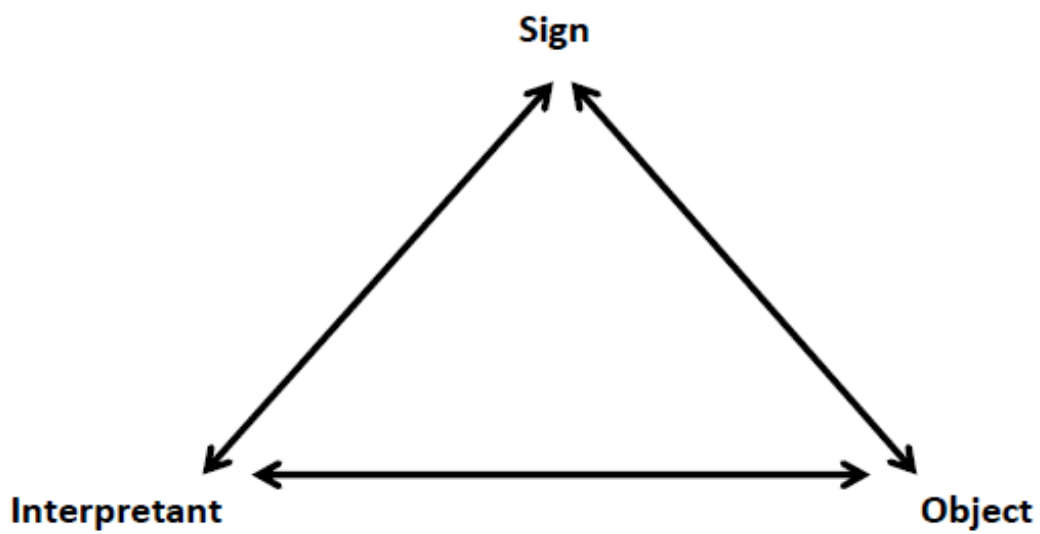

Figure 1. Relationship of concepts in semiotic analysis of meaning (Adapted from Fiske (2010) on basis of this Peirce model we would like to develop our research theoretical backbone.)

\section{Short Biography of a tennis player Rafael Nadal}

A world-famous Spanish tennis player's full name is Rafael Nadal Parera and his nickname is "Rafa" and/or "The King of Clay". Rafael Nadal was born on June 3, 1986 in Manacor (it is a town on the island of Mallorca, part of the Spanish autonomous community of the Balearic Islands in the Mediterranean see). R. Nadal was introduced to play tennis by his uncle Toni 
Nadal (a former professional tennis player) when Rafael was three years old. However, Rafael Nadal won an under-12 regional tennis championship when he was eight years old as a result his uncle, Toni Nadal, began to work with and give a lot of training to Rafael. When Rafael Nadal was just 12 years old, he won the Spanish and European tennis titles in his age group and he turned a professional tennis player at age 15 .

During his sport's carrier, Rafael Nadal has won 14 Grand Slam singles titles. In 2008 in Beijing he achieves the first Olympic Gold Medal in Spanish male tennis in singles. In addition, R. Nadal has reached a record number of titles in ATP World Tour Masters 1000 events in total 27 and 16 titles in ATP World Tour 500 tournaments. In 2004, 2009, and 2011 he was a member of the winning Spain Davis Cup team. Also, Rafael Nadal won four straight French Open titles from 2005 to 2008. In 2008 he won a Prince of Asturias award named for Spain's Crown Prince Felipe (now the King of Spain) and in 2011 in Abu Dhabi, Nadal was crowned as a Sportsman of the Year by the Laureus Award. Rafael Nadal has won many different tennis tournaments for almost a decade who has been the top leader and one of the best tennis players of the world (see Figure 2).

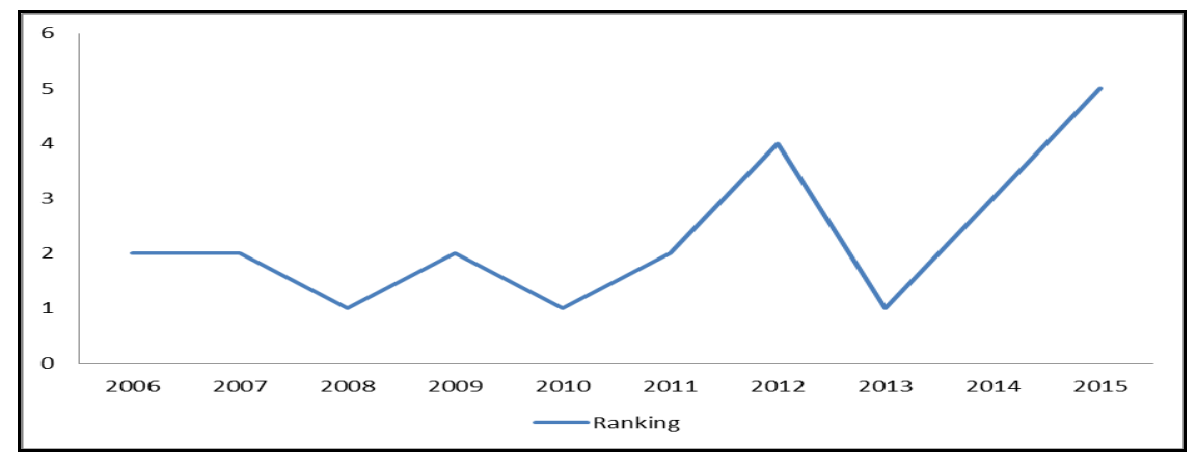

Figure 2. Rafael Nadal rankings history (Adapted from Players. Rafael Nadal, 2015: website)

\section{Public Image of Rafael Nadal}

During his all carrier Rafael Nadal has been also quite active in Spanish and the world's public space. In 2007, Rafael Nadal with the sponsor companies like Kia Motors, a watch brand Richard Mille, and other companies have created Rafa Nadal Foundation. The foundation helps socially discriminated children and teenagers who run the risk of exclusion by society. This foundation in October 2010 and 2014 has opened Anantapur Educational Centre in India and also Rafa Nadal Foundation Center, Education and Sport Palma de Mallorca.

In addition, a world famous tennis player has been representing different companies' marketing messages. From beginning of his professional carrier until now he has been an endorser or a sport celebrity who attracts many Spanish and international customers to buy products and services which are promoted by Rafael Nadal. He has been the message source from cookies to insurance policies ads. Therefore, not always Rafael Nadal was presenting products and services related to sports activities or equipment. In Table 1, you can find the list of companies that have been contracted Rafael Nadal for their commercial ads. The list is based on the search by authors on different Internet websites. 
Table 1

Advertisements Presented by Rafael Nadal

\begin{tabular}{|c|c|c|c|}
\hline Company Name & Product & Year & Website \\
\hline Tommy Hilfiger & Men's Underwear & 2015 & http://global.tommy.com/int/en/collections/start/14 \\
\hline Bacardi & Social Responsibility Ad & 2013 & http://www.bacardilimited.com/news/247 \\
\hline PokerStars & Online Poker's Game & Since 2012 & $\begin{array}{l}\text { https://www.pokerstars.es/es/blog/news/rafa nadal/2012/raf } \\
\text { a-nadal-protagonista-de-la-nueva-camp-118767.shtml }\end{array}$ \\
\hline Emporio Armani & $\begin{array}{l}\text { Men's Underwear } \\
\text { Men's Jeans }\end{array}$ & 2011 & $\begin{array}{l}\text { http://alive.armani.com/news/it/new-short-film-featuring- } \\
\text { nadal/ }\end{array}$ \\
\hline Babolat & $\begin{array}{l}\text { Racquet } \\
\text { Pack Bag }\end{array}$ & Since 2010 & http://www.rafaelnadal.com/ \\
\hline Quely & Cookies & Since 2010 & http://quely.com/es/publicidad \\
\hline Richard Mille & Watch & Since 2010 & http://www.richardmille.com/es/star/rafael-nadal/ \\
\hline Nike & $\begin{array}{l}\text { Men's Tennis Shirt, } \\
\text { Men's Tennis Shorts } \\
\text { Men's Tennis Jacket } \\
\text { Men's Tennis Shoe } \\
\text { Tennis Hat } \\
\text { Tennis Headband } \\
\text { Tennis Socks } \\
\text { Wristbands }\end{array}$ & Since 2009 & http://store.nike.com/us/en_us/pw/rafael-nadal/8s9 \\
\hline Lanvin Paris & $\begin{array}{l}\text { Lanvin L'Homme Sport } \\
\text { Fragrance }\end{array}$ & 2009 & $\begin{array}{l}\text { http://www.mimifroufrou.com/scentedsalamander/2009/03/1 } \\
\text { anvin_lhomme_sport_2009_front.html }\end{array}$ \\
\hline Maprfe & Maprfe in General & Since 2009 & $\begin{array}{l}\text { https://www.salaprensa.mapfre.com/ficha-nota- } \\
\text { prensa/724/nueva-campanya-publicitaria-marca-mapfre- } \\
\text { america-latina }\end{array}$ \\
\hline Balearic Islands & $\begin{array}{l}\text { Tourism in Balearic } \\
\text { Islands }\end{array}$ & 2009 & $\begin{array}{l}\text { http://www.illesbalears.es/accesible/index.jsp?isla }=002 \& \text { lan } \\
\mathrm{g}=\mathrm{ES} \& \mathrm{sec}=0024 \& \text { item }=00001552\end{array}$ \\
\hline Banesto Bank & Banesto Bank in General & Since 2008 & $\begin{array}{l}\text { http://cincodias.com/cincodias/2007/10/23/empresas/119330 } \\
\text { 6341_850215.html }\end{array}$ \\
\hline L’Oréal & $\begin{array}{l}\text { Anti-Dandruff Shampoo } \\
\text { "Elvive" }\end{array}$ & 2007 & $\begin{array}{l}\text { http://www.trendencias.com/marcas/rafa-nadal-imagen-de- } \\
\text { loreal }\end{array}$ \\
\hline Kia Motors & Cars & Since 2006 & $\begin{array}{l}\text { http://m.kia.com/ph/ExperienceKia/Sponsorship/RafaelNada } \\
\text { l/index.htm }\end{array}$ \\
\hline Time Force & Sport's Watch & 2006 & $\begin{array}{l}\text { http://www.europapress.es/deportes/noticia-pau-gasol-rafa- } \\
\text { nadal-participan-palma-rodaje-spot-publicitario-marca- } \\
\text { relojes-time-force-20060618132420.html }\end{array}$ \\
\hline Cola-Cao & Chocolate Drink & Since 2005 & https://www.youtube.com/watch?v=QCHaL35zUEA \\
\hline
\end{tabular}

*Source: Authors elaboration (2016)

\section{Method}

\section{Content Analysis Technique}

Content analysis is a set of qualitative research methods for analysing the symbolic content of any communication. The basic idea of this technique is to reduce the total content of a communication to a set of categories that represent some characteristics of research interest. Thus, content analysis technique may involve the systematic description of either verbal or nonverbal materials (Singleton \& Straits, 2010, p. 420). The main idea of content analysis is an attempt to achieve a measure of objectivity and it is addressed by the creation of specific rules called criteria of selection which have to be established before the data can be analysed (Gray, 2009). Other authors such as Hair, Bush, and Ortinau (2006) confirm that content analysis technique is an appropriate analysis tool to use in any type of qualitative research 
and it is possibly the most widely used formalized procedure by researchers in their efforts to create meaningful findings. Also, Krippendorff (1980, p. 51) notes that "a content analysis research is motivated by the search for techniques to infer from symbolic data what would be either too costly, no longer possible, or too obtrusive by the use of other techniques". Denscombe (2003, p. 221) confirms that it is a method that can be used with any "text", whether it is in the form of writing, sounds or pictures. Similarly and simply, Holsti (1969, p. 14) suggests to use a content analysis technique as "any technique for making inferences by objectively and systematically identifying specified characteristics of messages".

Also according to the formerly quoted author Krippendorff's (1980) six questions must be asked in every content analysis research that are the following:

1) Which data are analysed?

2) How are they defined?

3) What is the population from which they are drawn?

4) What is the context relative to which the data are analysed?

5) What are the boundaries of the analysis?

6) What is the target of the inferences?

According to Denscombe (2003), in the content analysis research process should use a logical and relatively straightforward procedure such as choosing an appropriate sample of texts (images, pictures, etc.); break the text into smaller component units; develop relevant categories for analysing the data; and coding the units in line with the categories.

In this study, the content analysis technique was applied in order to analyse the advertisements' messages where has appeared a tennis player Rafael Nadal. The ads messages which could find on different Internet portals were used, basically the official websites of the companies that have been contracted Rafael Nadal like a celebrity for promoting their products and services. Peirce's three concept semiotics model that has been explained before was used in this study. The main idea of this analysis was to find out what "sign" as a sport celebrity represents a tennis player Rafael Nadal in each of the advertisement.

\section{Face-to-Face Survey Technique}

Nowadays, a face-to-face survey technique falls into two main categories, namely analytical and descriptive. Analytical survey takes many of the features of experimental, deductive research and so places an emphasis on reliability of data and statistical control of variables, sample size, etc. The descriptive survey exploits inductive view and often the form of openended questions. Thus, a descriptive survey may be quite ethnographic in character (Gray, 2009). However, the survey technique is applied to research basically when individuals are the elements of analysis with large population and it is believed to be probably the best method available to social researchers to elicit authentic and direct data, which needs to exploit careful sampling that reflects the characteristics of larger population. The purpose of using a survey is often to catch a range of facts or attitudes or information on behaviors (Babbie, 2014; Stokes, 2011). 


\section{Questionnaire}

As mentioned already, surveys are structured by questionnaires to collect data (Babbie, 2014). Consequently, a questionnaire has four main purposes in the data collection process: to collect relevant data, to make data comparable, to minimize bias, and to motivate the respondent. Since data collection process is through questionnaires, therefore, a careful consideration should be taken in designing them. A poorly designed questionnaire will collect inappropriate or inaccurate data and so negate the whole purpose of the research (Crouch \& Housden, 2003).

In that sense, the sample size of this study is 328 participants with a 22 questions surveyquestionnaire that has been undertaken at the exit of one underground station in Madrid (Vicálvaro underground station with a huge influx of people). The applied questionnaire has been structured in 3 blocks in order to gather information about this piece of research:

Block 1: General questions concerning a sport celebrity as a message source;

Block 2: Questions related to the Spanish tennis player Rafael Nadal as a message source;

Block 3: Socio-demographic profile of the participants.

The questionnaire (in Spanish and English languages) has been pre-tested and polished accordingly before the final field work (Cronbach Alpha of 0.786). It took over 9 minutes to complete one questionnaire and with a refusal rate of $11.1 \%$ (we have approached 382 subjects and 54 have rejected to participate in the survey). The non-response rate (unanswered questions) is very low with less than $2.8 \%$ missing data out 14432 of total responses. For measuring the variables of the questions, some five-point Likert-type scales are applied to determine the sensibilities of these variables. The advantages of a five-point or a four-point Likert-type scale are discussed by some researchers believing that the answers from a four-point scale do not really follow a normal distribution (is skewed too much on one side).

Questionnaires have been handed-out whenever possible over different days and time periods (a mixture of weekends and weekdays) to ensure that all age and social groups are sampled. In particular, the questionnaires were carried out from Friday February 12, 2016 to Thursday February 18, 2016 (both dates included). The selected timetable corresponds from 09.00 to 14.00 . Regarding the place, the poll-takers carried out the questionnaires at the exit of Vicalvaro underground station.

The total population consisted of all commuters of Vicálvaro underground station who are 18 years-old or older. The visitors filled out the questionnaire on 9 minutes as average. To be reliable, participants have been selected on a simple random basis- i.e. by approaching every 7 commuter who exits the underground. This technique provided a simple random sampling (probability sampling) of the respondents with a Confidence Level of 95\% and a sampling error (with assumption of most conservative scenario $\mathrm{p}=\mathrm{q}=0.5$ ) of $+11.3 \%$.

Finally, the obtained data have been worked out through software Statistical Package for Social Sciences (IBM SPSS, V.20) for univariate (frequency), bivariate (Pearson correlation) and multivariate analysis (multiple linear regressions). 


\section{Technical Datasheet}

In a nutshell, all the steps taken regarding the methodology for this research are wrapped up in the following Table 2:

Table 2

Technical Datasheet of the Research

\begin{tabular}{|c|c|c|}
\hline Features & Content Analysis & Face-to-Face Survey \\
\hline Participants & $\begin{array}{l}16 \text { ads Online: } \\
\text {-Official Company Websites }\end{array}$ & $\begin{array}{l}328 \text { Subjects at the Exit of Vicálvaro Underground } \\
\text { Station }\end{array}$ \\
\hline Sampling Technique & Not Applicable & Simple Random Sampling \\
\hline Sampling Error & Not Applicable & $+11,3 \%$ \\
\hline Confidence Level & Not Applicable & $95 \%$ (with $\mathrm{p}=\mathrm{q}=0,5$ ) \\
\hline Duration & Not Applicable & $9 \mathrm{~min}$. \\
\hline Dates of Implementation & $\begin{array}{l}\text { Ads where has Participated Rafael Nadal } \\
\text { Since } 2005 \text { Until } 2015\end{array}$ & $\begin{array}{l}\text { From Friday } 12 \text { th February } 2016 \text { to Thursday } 18 \text { th } \\
\text { February } 2016 \text { (Both Dates Included). }\end{array}$ \\
\hline Analysis Technique & $\begin{array}{l}\text { Content Analysis: } \\
\text {-Visual Images } \\
\text {-General Textual Context of the Ad }\end{array}$ & $\begin{array}{l}\text { Statistical Procedures: } \\
\text {-Univariate Analysis (Frequency) } \\
\text {-Bivariate Analysis (Pearson Correlation) } \\
\text {-Multivariate Analysis (Multiple Linear } \\
\text { Regression) }\end{array}$ \\
\hline $\begin{array}{l}\text { Software Used for the Analysis } \\
\text { Technique }\end{array}$ & Not Applicable & IBM SPSS V.20 \\
\hline
\end{tabular}

* Source: Authors Elaboration (2016)

\section{Results}

\section{Content Analysis}

As it was explained in the part of methodology, our content analyses of the ads where have appeared the Spanish tennis player Rafael Nadal between 2005 and 2015, are based on Peirce's three concept semiotics model. The results of the content analysis are presented in Table 3.

Table 3

Analysis of Advertisements

\begin{tabular}{|c|c|c|}
\hline OBJECT & SIGN & INTERPRETANT \\
\hline $\begin{array}{l}\text { Company's Advertised } \\
\text { Product/Service }\end{array}$ & $\begin{array}{l}\text { Image/Effect which is } \\
\text { Represented in Message by } \\
\text { Rafael Nadal }\end{array}$ & Message's Consumer \\
\hline $\begin{array}{l}\text { "Tommy Hilfiger" } \\
\text { Men's Underwear }\end{array}$ & $\begin{array}{l}\text { Very Seductive Male's } \\
\text { Image }\end{array}$ & $\begin{array}{l}\text { Males Within Age Group } 16 \text { and } 65 \text { (National/ } \\
\text { International Markets) }\end{array}$ \\
\hline $\begin{array}{l}\text { "Bacardi" } \\
\text { Drink Alcohol Responsibly }\end{array}$ & $\begin{array}{l}\text { Serious Sportsman's } \\
\text { Image }\end{array}$ & $\begin{array}{l}\text { Young People and Adults } \\
\text { (National/ International Markets) }\end{array}$ \\
\hline $\begin{array}{l}\text { "PokerStars" } \\
\text { Online Poker's Application }\end{array}$ & $\begin{array}{l}\text { Attractive Male's Image } \\
\text { Who Likes to Win }\end{array}$ & $\begin{array}{l}\text { Online Poker Players Who Use Smart Phones } \\
\text { (National/ International Markets) }\end{array}$ \\
\hline $\begin{array}{l}\text { "Emporio Armani" } \\
\text { Men's underwear and } \\
\text { Men's jeans }\end{array}$ & $\begin{array}{l}\text { Very seductive male's } \\
\text { image }\end{array}$ & $\begin{array}{l}\text { Males Within Age Group } 16 \text { and } 40 \\
\text { (National/ International Markets) }\end{array}$ \\
\hline $\begin{array}{l}\text { "Babolat" } \\
\text { Racquet }\end{array}$ & $\begin{array}{l}\text { Serious Sportsman's } \\
\text { Image Who Always Wins }\end{array}$ & $\begin{array}{l}\text { Professional Tennis Players/ } \\
\text { Consumers Who Belong to Medium /High Class } \\
\text { and Who Play Tennis in Their Free Time } \\
\text { (National/ International Markets) }\end{array}$ \\
\hline
\end{tabular}




\begin{tabular}{|c|c|c|}
\hline $\begin{array}{l}\text { "Quely" } \\
\text { Cookies }\end{array}$ & $\begin{array}{l}\text { Comic and funny tennis } \\
\text { player }\end{array}$ & $\begin{array}{l}\text { Any Age and Gender } \\
\text { (National/ International Markets) }\end{array}$ \\
\hline $\begin{array}{l}\text { "Richard Mille" } \\
\text { RM 27-02 Rafael Nadal } \\
\text { Luxury Watch }\end{array}$ & $\begin{array}{l}\text { Serious Sportsman's } \\
\text { Image Who Always Wins }\end{array}$ & $\begin{array}{l}\text { Professional Tennis Players/ Sportsmen } \\
\text { Active Consumers Who Belong to Medium/ } \\
\text { High Class } \\
\text { (National/ International Mmarkets) }\end{array}$ \\
\hline $\begin{array}{l}\text { "Nike" } \\
\text { Different Clothing } \\
\text { Garments }\end{array}$ & $\begin{array}{l}\text { Serious Sportsman's } \\
\text { Image Who Always Wins }\end{array}$ & $\begin{array}{l}\text { Males Who Like Active Sport's Life Within } \\
\text { Age Group } 16 \text { and } 65 \text { (National/ International } \\
\text { Markets) }\end{array}$ \\
\hline $\begin{array}{l}\text { "Lanvin Paris" } \\
\text { Lanvin L'homme Sport } \\
\text { Parfume }\end{array}$ & $\begin{array}{l}\text { Strong, Serious, and } \\
\text { Seductive Male's Image }\end{array}$ & $\begin{array}{l}\text { Males Within Age Group } 16 \text { and } 65 \\
\text { (National/ International Markets) }\end{array}$ \\
\hline $\begin{array}{l}\text { "Mapfre" } \\
\text { Insurance Company in } \\
\text { General }\end{array}$ & $\begin{array}{l}\text { Serious Sportsman's } \\
\text { Image }\end{array}$ & $\begin{array}{l}\text { Males and Females, } \\
\text { Different Age Groups } \\
\text { (National/ International Markets) }\end{array}$ \\
\hline $\begin{array}{l}\text { Tourism Possibilities in } \\
\text { "Balearic Islands" }\end{array}$ & $\begin{array}{l}\text { Attractive Young Male's } \\
\text { Image }\end{array}$ & $\begin{array}{l}\text { Young Males and Females } \\
\text { (National/ International Markets) }\end{array}$ \\
\hline $\begin{array}{l}\text { "Banesto Bank" } \\
\text { Bank in General }\end{array}$ & $\begin{array}{l}\text { Serious Sportsman's } \\
\text { Image }\end{array}$ & $\begin{array}{l}\text { Males and Females, } \\
\text { Different Age Groups } \\
\text { (National/ International Markets) }\end{array}$ \\
\hline $\begin{array}{l}\text { "L’Oréal" } \\
\text { Antidandruff Shampoo }\end{array}$ & $\begin{array}{l}\text { Serious Sportsman's } \\
\text { Image Who Always Wins }\end{array}$ & $\begin{array}{l}\text { Males and Females, } \\
\text { Different Age Groups, } \\
\text { have Problems with Dandruffs } \\
\text { (National Market) }\end{array}$ \\
\hline $\begin{array}{l}\text { "Kia Motors" } \\
\text { Different Kia Cars }\end{array}$ & $\begin{array}{l}\text { Serious Sportsman's } \\
\text { Image Who Always Wins }\end{array}$ & $\begin{array}{l}\text { Young Males and Females } \\
\text { (National/ International Markets) }\end{array}$ \\
\hline "Time Force" & $\begin{array}{l}\text { Attractive Young Male’s } \\
\text { Image }\end{array}$ & $\begin{array}{l}\text { Males Within Age Group } 16 \text { and 40, } \\
\text { Who Belong to Medium /High Class } \\
\text { (National/ International Markets) }\end{array}$ \\
\hline "Cola-Cao" & $\begin{array}{l}\text { Comic and Funny Young } \\
\text { Guy }\end{array}$ & $\begin{array}{l}\text { Children and Young People } \\
\text { (National Market) }\end{array}$ \\
\hline
\end{tabular}

* Source: Authors elaboration (2016)

\section{Univariate (Survey)}

A wide range of age groups mainly young people between 20 and 24 participated in this survey, $64.9 \%$ of the participants were males and $35.1 \%$ were females. This fact could be explained to the closeness of the Vicálvaro underground station to the Rey Juan Carlos University where the flow of the students is very high.

As mentioned before, the Spanish tennis player Rafael Nadal during his carrier has advertised 16 different companies' products and services in a Spanish market between 2005 and 2015, but as shown in Table 4, the results of our investigation showed that as a message source, he is mainly associated with "Nike" (26.2\%) and "Kia Motors" (23.2\%). Hence, we can observe that some ad messages where Rafael Nadal has appeared, respondents even did not mention such as Quely, Bacardi, PokerStars, Richard Mille, Lanvin Paris, L'Oréal, and Cola-Cao. 
Table 4

Companies Associated with Rafael Nadal as a Message Source

\begin{tabular}{lcc}
\hline Company & Frequency & Percent \\
\hline Emporio Armani & 35 & 10.7 \\
Babolat & 46 & 14.0 \\
Tommy Hilfiger & 8 & 2.4 \\
Nike & 86 & 26.2 \\
Mampfre Insurance & 12 & 3.7 \\
Balearic Island & 1 & 3 \\
Banesto Bank & 40 & 12.2 \\
Kia Motors & 76 & 23.2 \\
Time Force & 24 & 7.3 \\
Total & 328 & 100.0 \\
\hline
\end{tabular}

* Source: Authors elaboration (2016)

\section{Bivariate (Survey)}

As presented in Table 5, we can perceive by the respondents' answers that there is correlation between their willing to purchase products/services which are not related to sports and endorsed by Rafael Nadal and their opinion about the emotional message appeal which is more appropriate for famous sportsmen. This correlation could mean that the products/services which are not related to sports in ads should have some emotional and human kind appeal. Hence, people do not want to see only a sportsman as a winner but as a normal human being and a part of our society's member who has the same daily problems. In addition, correlations between respondents' credibility in ads are not related to sports and endorsed by Rafael Nadal and their opinion about the emotional message appeal which is more appropriate for famous sportsmen affirm that for the respondents what was more important and credible ads were those which were not related to sports and had presented in very warm and kind way. On the other hand, the results obtained from the correlation between their willing to purchase products/services which are not related to sports and endorsed by Rafael Nadal and their willing to purchase products/services that are related to sports and endorsed by Rafael Nadal revealed that the Spanish people like to purchase products/services which are related and not related to sports but endorsed by Rafael Nadal, and by this we understand that a tennis player is really loved in his country.

Table 5

Correlations $(N=328)$

\begin{tabular}{|c|c|c|c|c|c|c|c|c|}
\hline Variables & 1 & 2 & 3 & 4 & 5 & 6 & 7 & 8 \\
\hline Emotional Appeal & 1 & $-0.43^{* *}$ & $-.037^{* *}$ & 0.070 & $-0.30 * *$ & $-0.57 * *$ & $-0.22 * *$ & $0.58 * *$ \\
\hline Rational Appeal & $-0.43^{* *}$ & 1 & $0.30^{* *}$ & $-0.20 * *$ & $-19 * *$ & 0.09 & $0.33 * *$ & $-0.18 * *$ \\
\hline Sex Appeal & $-0.37^{* *}$ & $0.30^{* *}$ & 1 & $-0.33 * *$ & $-0.32 * *$ & $-0.31 * *$ & $-0.20 * *$ & $-0.47 * *$ \\
\hline Humorous Appeal & 0.07 & $-0.20^{* *}$ & $-0.33^{* *}$ & 1 & $0.45 * *$ & $0.29 * *$ & $0.27 * *$ & 0.001 \\
\hline $\begin{array}{l}\text { Purchasing Products } \\
\text { related to Rafael Nadal }\end{array}$ & $-0.30^{* *}$ & $-0.19^{* *}$ & $-0.32^{* *}$ & $0.45^{* *}$ & 1 & $0.71 * *$ & $0.17 * *$ & $-0.18 * *$ \\
\hline $\begin{array}{l}\text { Purchasing Products Not } \\
\text { related to Rafael Nadal }\end{array}$ & $-0.57^{* *}$ & 0.09 & $-0.31^{* *}$ & $0.29 * *$ & $0.71 * *$ & 1 & $0.19 * *$ & $-0.49 * *$ \\
\hline $\begin{array}{l}\text { Credibility of ads } \\
\text { related to Rafael Nadal }\end{array}$ & $-0.22^{* *}$ & $-0.33^{* *}$ & $-0.20^{* *}$ & $0.27 * *$ & $0.17 * *$ & $0.19 * *$ & 1 & 0.04 \\
\hline Credibility of ads Not & $0.58^{* *}$ & $-0.18^{* *}$ & $-0.47^{* *}$ & 0.001 & $-0.18 * *$ & $-0.49 * *$ & 0.04 & 1 \\
\hline
\end{tabular}




\section{Multivariate (Survey)}

The following assumption is criticized because of the linearity of conditional mean where $\mathrm{Y}$ stands for at least two predictors $\mathrm{X}$ (covariate, regression) for each observation:

$\boldsymbol{P}$ (Rafael Nadal should appeari Only in ads which are related to the sports'produtes

$$
\begin{aligned}
& (\text { servicas? })= \\
& \boldsymbol{\beta}_{0}+\boldsymbol{\beta}_{1}(\text { Age })+\boldsymbol{\beta}_{2}(\text { Gender })+\boldsymbol{\beta}_{g} \text { (Emotional appeal) }+\boldsymbol{\beta}_{4}(\text { Rattonal appeal) })+ \\
& \boldsymbol{\beta}_{5}(\text { Sex appeal })+\boldsymbol{\beta}_{6}(\text { Humourous appeal) } \\
& P(Y)=\mu_{0}+\beta_{1} X_{1}+\beta_{2} X_{21}+\beta_{3} X_{3}+\beta_{4} X_{4}+\mu_{5} X_{5}+\mu_{6} X_{8}
\end{aligned}
$$

Where $\beta_{0}$ is called the intercept and the $\beta \mathrm{j}$ are called slopes or coefficients.

Based on this mean function, we can determine if "Rafael Nadal should appear only in ads which are related to the sports' products/services" as long as it goes with age of the participants, gender of the participants, emotional appeal of the ad, rational appeal of the ad, sex appeal of the ad, and humorous appeal of the ad. Thus, some assumptions have been made for designing this model including linearity, independence, normality, and equal variation of the selected variables.

According to Table 6, a high proportion of the variance in the data is explained by the model, $R=86 \%$. Furthermore, the prediction (Table 6) of "Rafael Nadal should appear only in ads which are related to the sports' products/services" is simultaneously influenced by the age of the participants, gender of the participants, emotional appeal of the ad, rational appeal of the ad, sex appeal of the ad, and humorous appeal of the ad.

Table 6

The Results of Multiple Regression Analyses for Products Related to Rafael Nadal

\begin{tabular}{lccc}
\hline & & Model & $\beta$ \\
\cline { 2 - 4 } Variables & $B$ & $S E B$ & $-0.52^{*}$ \\
Emotional Appeal & -0.85 & 0.06 & $-0.53^{*}$ \\
Rational Appeal & -0.62 & 0.04 & $0.12^{*}$ \\
Humorous Appeal & 0.18 & 0.04 & $-0.33^{*}$ \\
Sex Appeal & -0.40 & 0.04 & $0.14^{*}$ \\
Age & 0.01 & 0.004 & -0.48 \\
Gender & -0.85 & 0.05 & \\
$R$ & & 0.86 & \\
$R^{2}$ & & 0.74 & \\
Adjusted $R^{2}$ & & 0.74 & \\
$F$ for Change in $R^{2}$ & & 0.64 &
\end{tabular}

\section{Conclusions}

The use of popular sportsmen/sportswomen in marketing communication strategies is a common way of attracting national and international consumers, but always there arouses the question of the credibility of the message when the sportsman/sportswomen appear in many 
different companies' messages. We know that most of the times, sportsman/sportswomen agree to be endorser of the companies which pay more. Could we call that with strong words as an "advertising prostitution"?

Our study on a credibility of a message source has been based on the Spanish tennis player Rafael Nadal's phenomenon. He has appeared in 16 different company marketing messages during ten years period and has showed different images from a serious tennis player to a seductive male. Hence, companies that have contracted Rafael Nadal also have used diverse message appeals from humorous to sex appeal. Therefore, we can affirm and conclude that Spanish people like to purchase products which are and which are not related to sports' products/services but are endorsed by Rafael Nadal. They like to see him also in different appeals which of course depend on gender and age groups. Therefore, here we could affirm that "advertising prostitution" by Rafael Nadal is widely accepted by a Spanish market and there is nothing wrong for having credibility to advertise one or many companies' products.

During our research project there also have appeared some limitations which we would like to mention and we have to take into consideration for the analysis of results: Messages' analysis, where has appeared Rafael Nadal, were based only on a digital format sources (different websites) due to limited access to other formats (TV, billboards, etc.) which have been used during the last decade; limited execution place at Vicálvaro underground station, and limited possibilities to study a target population internationally, as Rafael Nadal is a world famous tennis player. Further research are required to study other world famous sport celebrities and their transmitted credibility in advertising messages, and how these messages invite national and international consumers to purchase different companies' products and services.

\section{References}

Babbie, E. R. (2014). The basics of social research (6 ${ }^{\text {th }}$ ed.). Wadsworth: Cengage Learning.

Belch, G. E., \& Belch, M. A. (2012). Advertising and promotion; An integral marketing communication perspective $\left(9^{\text {th }}\right.$ ed.). New York: McGraw-Hill.

Chandler, D. (2007). Semiotics: The basics ( ${ }^{\text {nd }}$ ed.). New York: Routledge.

Crouch, S., \& Housden, M. (2003). Marketing research for managers ( $3^{\text {rd }}$ ed.). Burlington, MA, USA: ButterworthHeinemann.

Denscombe, M. (2003). The good research guide ( ${ }^{\text {nd }}$ ed.). Berkshire: Open University Press.

Eco, U. (1979). A theory of semiotics. Bloomington: Indiana University Press.

Evans, R. B. (1988). Production and creativity in advertising. London: Pitman Publishing.

Fiske, J. (2010). Introduction to Communication Studies ( $3^{\text {rd }}$ ed.). London: Routledge.

Gray, D. E. (2009). Doing research in the real world ( $2^{\text {nd }}$ ed.). London: Sage.

Hair, J., Bush, R., \& Ortinau, D. (2006). Marketing research within a changing information environment (3 ${ }^{\text {rd }}$ ed.). New York: McGraw-Hill.

Hawkins, D. I. \& Mothersbaugh, D. L. (2013). Consumer behavior: Building marketing strategy (12 ${ }^{\text {th }}$ ed.). New York: McGraw-Hill.

Holsti, O. R. (1969). Content analysis for the social sciences and humanities. Reading, MA: Addison-Wesley.

Keller, K. L. (1998). Strategic brand management: Building, measuring, and managing brand equity ( $1^{\text {st }}$ ed.). Upper Saddle River, NJ: Prentice-Hall.

Kotler, P., \& Armstrong, G. (2012). Principles of marketing (14 ${ }^{\text {th }}$ ed.). Upper Saddle River, NJ: Pearson Prentice Hall. 
Krippendorff, K. (1980). Content analysis: An introduction to its methodology. Newbury Park, CA: Sage.

Misra, S., \& Beatty, S. E. (1990). Celebrity spokesperson and brand congruence: An assessment of recall and affect. Journal of Business Research, 21(2), 159-173.

Ruihley, B. J., Runyan, R. C., \& Lear, K. E. (2010). The use of sport celebrities in advertising: a replication and extension. Sport Marketing Quarterly, 19(3), 132-142.

Silverman, K. (1983). The subject of semiotics. New York: Oxford University Press.

Singleton, R. A. JR, \& Straits, B. C. (2010). Approaches to social research (5 ${ }^{\text {th }}$ ed.). New York, NY: Oxford University Press.

Solomon, M., Bamossy, G., Askegaard, S., \& Hogg, M. K. (2006). Consumer behaviour: A European Perspective ( $3^{\text {rd }}$ ed.). Harlow: Pearson Education Limited.

Stokes, P. (2011). Key concepts in business and management research methods. Basingstoke: Palgrave Macmillan.

Stone, G., Joseph, M., \& Jones, M. (2003). An exploratory study on the use of sports celebrities in advertising: A content analysis. Sport Marketing Quarterly, 12(2), 94-102. 